Bangl. J. Vet. Med. (2009). 7(1) : 275 - 280

\title{
COMPARATIVE EFFICACY OF DADMARDAN, NEEM AND IVERMECTIN AGAINST SKIN LESIONS IN CALVES AND GOATS
}

\author{
M. M. Rahman, M. Mostofa, V. G. Barman, R. Mian and S.A. Mamun
}

Department of Pharmacology, Bangladesh Agricultural University, Mymensingh-2202, Bangladesh.

\begin{abstract}
The experiment was conducted to investigate the comparative efficacy of indigenous medicinal plants, dadmardan (Cassia alata) and neem (Azadiracta indica) and ivermectin against skin lesions in calves and goats. Twelve calves of 8- 12 months and twelve goats of 1-2 years of age irrespective of sex having skin lesions (ringworm, scabies, humpsore, wounds) were used in the experiment. Selected calves and goats were divided into four equals groups (group A,BC and D), each group consists of 3 calves and 3goats. The group A kept as control group. The group B was treated with ivermectin (Cevamec 1\% ${ }^{(\mathrm{R})} @ 200 \mathrm{ug} / \mathrm{kg}$ body weight subcutaneously ,group C with dadmardan ointment (30\%) ointment topically and group D with 30\% combined ointment(dadmardan and neem leaves) topically. Calves and goats treated with ivermectin were almost cured within18 days and the rate of healing was $98.36 \% \& 99.03 \%$ respectively whereas animals treated with dadmardan ointment cured at $30^{\text {th }}$ days of treatment in calves and at $27^{\text {th }}$ days of treatment in goats and the rate of healing was $99.80 \% \& 99.88 \%$ respectively and those treated with combined ointments of dadmardan and neem leaves cured at $27^{\text {th }}$ days of treatment in calves and at $24^{\text {th }}$ day of treatment in goats and the rate of healing was $99.94 \%$ \& $99.35 \%$ respectively. Ivermectin treatment was more effective in comparison to other treatments considering the time required for healing. On the other hand, treatment with the onitmemts of indigenous medicinals plants were more effective considering the rate of healing. It may be concluded that the ointments of indigenous medicinals plants (dadmardan ointment and the combined ointment of dadmardan and neem leaves) may be used as alternative drugs for the treatment of skin lesions in calves and goats.
\end{abstract}

Key words: Dadmardan,Neem ,Ivermectin and skin lesions

INTRODUCTION

Animal welfare has, in recent years, become a prominent issue both inside and outside of industry (Cullen,1991).As Bangladesh is an agro based developed country, livestock is firmly integrated into the economic structure of farm and village life. It is considered to the backbone of agriculture (Anon, 1985).It play an important role to promote human health by supplying animal protein in the form of milk and meat. Very recently Government has taken "Poverty alleviation programme" by increasing goat production. The normal healthy skin acts as an organ of protection and plays an important role to maintain homeostasis. Various skin diseases are prevalent in livestock, which may cause a serious loss in the production performance. Skin diseases were found to be the second major group (20.63\%) of calf diseases (Debnath et al .1990). Dermatitis (9.64\%) was recorded as the major skin diseases of calves, followed by ectoparasitism (2.54\%) and skin wound (2.13\%) with limited incidence of burn (0.36\%) and myiasis $(0.24 \%)$ cases (Samad, 2003). Bangladesh leathers have good inherent quality because of warmer climatic condition and food habits. Leathers made from hides and skins of animals maintained in warmer climates are superior to those of animals raised in colder climates,but such advantages are overshadowed by various defects (FAO, 1997).Surprising leather defects due to skin disease, postmortem defects or curing defects, and industrial processing defects, cut about $55.2 \%$ value of leathers resulting in annual economic loss of approximately Taka 818 core (US\$ 220.95 million).Among such economic looses , US\$ 24.1 million was due to Black Bengal goats skin defects in Bangladesh (Dey and Nooruddin ,1993).

Ivermectin a new patent drug, which is effective against both endo and ecto parasites and skin lesions of anaimals. Recently much interest in the field of medicinal plants has been grown in all over the world. Many countries have already come to realize the medicinal plants as a potential means of alleviate therapeutic agent and also their economic value (Mostofa,1983). Various types of herbal extracts showed the larvicidal and acaricidal effects (Chungsamarnyart,et al. 1991). In fact, the preliminary study on the traditional system of Veterinary Medicine by Food and Agriculture Organization (FAO,1980), revealed that indigenous system for the treatment of animal diseases is popular in man in Asian countries including Bangladesh. There are several indigenous medicinal plants (neem, pineapple, tobacco) have anthelmintics action( Nath, 1983, Mostofa, 1983 and Hossain, 1994) and used against both ecto and endo parasites in Bangladesh, (Mostofa, 1983, Safique 1983, Mannan, 1997).At present there are no available effective drugs without toxicities. Although ivermectin is safe and effective against both ecto and endo parasites of animals but it is expensive. In contrast, the alternative cheapest and available source of drug is herbal therapy. Experimental investigations, therefore, is imperative to asses the 


\section{M. Rahman and others}

therapeutic value of indigenous herbal plants and leaves. Research work in this field is till now limited in our country. From this point of view, this research work has been designed to investigate the comparative efficacy of indigenous medicinal plants (dadmardan and neem ) and ivermectin against skin lesions in calves and goats with their adverse effects if any.

\section{MATERIALS AND METHODS}

The experiment was conducted from July 2007 to August 2007in the Department of Pharmacology, Bangladesh Agricultural University on twelve calves of 8-12 months and twelve goats of 1-2 years age irrespective of sex having skin lesions (ringworm, scabies, humpsore, wounds) to determine the comparative efficacy of some indigenous medicinal plants (dadmardan and neem) and ivermectin against skin lesions in calves and goats.

\section{Collection of Drugs, Medicinal Plants and Chemicals}

Injectable ivermectin preparation (Cevamec $1 \%{ }^{(\mathrm{R})}$, ACI Bangladesh Ltd.), Vaseline (used as vehicle in the herbal ointment) and Butylated hydroxy anisole (BHA, Loba chemie Pvt Ltd, Mumbai, India) (used as preservative in the ointment) was purchased from local market .The leaves of the dadmardan (Cassia alata) and neem (Azadiracta indica) were collected from the medicinal plant garden, Bangladesh Agricultural University.

\section{Preparation of test materials}

The fresh leaves (dadmardan and neem) were dried in hot air oven and then grinded (three times) separately by grinder to fine particles. The particles were then sieved separately by a sieve.300 gm $30 \%$ combined ointment (15 gm neem leaves, 15 gm dadmardan leaves, $69.5 \mathrm{gm}$ vaseline and $0.5 \mathrm{gm}$ of BHA) and $300 \mathrm{gm}$ of $30 \%$ ointment of dadmardan leaves (30 gm leaves, $69.5 \mathrm{gm}$ Vaseline and $0.5 \mathrm{gm}$ BHA) was prepared and the ointments were taken in small plastic tubes (30 tubes) of 20 gm capacity/tube.

\section{Experimental schedule}

Selected calves and goats were divided into four equal groups ( 3 calves and 3 goats) and treated with indigenous medicinal plants and Ivermectin as per following schedule:

\begin{tabular}{|c|c|c|}
\hline Groups of animal & & Drug with dose and route \\
\hline Group A & $:$ & Without treatment (Infected control group) \\
\hline Group B & : & $\begin{array}{l}\text { Ivermectin (Cevamec } 1 \% @ @ @ 200 \mu \mathrm{g} / \mathrm{kg} \text { body } \\
\text { weight, SC at } 1^{\text {st }}, 7^{\text {th }} \& 14^{\text {th }} \text { day }\end{array}$ \\
\hline Group C & $:$ & $\begin{array}{l}\text { Dadmardan ointment (30\% ointment) topically } \\
\text { twice daily after washing the lesions by potassium } \\
\text { permanganate solution ,30 days for calves and } 27 \\
\text { days for goats }\end{array}$ \\
\hline Group D & : & $\begin{array}{l}30 \% \text { combined ointment (dadmardan and neem } \\
\text { leaves) topically twice daily after washing the } \\
\text { lesions by potassium permanganate solution, } 27 \text { days } \\
\text { for calves and } 24 \text { days for goats. }\end{array}$ \\
\hline
\end{tabular}

\section{Statistical Analysis}

Results of treatment in all groups were analyzed by using student's test (t-test).

\section{RESULTS AND DISCUSSION}

Ivermectin is a semi-synthetic derivative of avermectin (Macrocyclic lactone) that has a broad spectrum of activity against a wide variety of arthropods and nematodes of wild and domestic animals and human. Its use has revolutionized the treatment of nematode and arthropod parasites in animals and has provided hope for the control or even eradication of filariasis in humans. Hence, ivermectin has earned the title of 'wonder drug' (Woodruff and Brug, 1986). In the present study, application of ivermectin subcutaneously @ 1 ml/50 kg body weight was found 98.36\% and 99.03\% effective in calves and goats respectively without any side effect. Animals with both larger and smaller lesions were cured within 18 post treatment days. After the first treatment, the percentage of healing of the lesion was not so remarkable. 


\section{Comparative efficacy of medicinal plants and ivermectine}

In subsequent treatment on the $7^{\text {th }}$ and $14^{\text {th }}$ day the healing was remarkable with scar tissue formation and growth of new hair around the scar tissue. This may be due to strong anti parasitic action of the ivermectin. The present finding has close correlation with the finding of Gill et al. (1988) and Venugopal et al. (1992).The efficacy of the ivermectin may vary due to variation of species and geographical location ( Gill et al. 1988 ;Venugopal et al. 1992 ,Taher,2005). Topical application of both the ointments were found highly effective without any side effect against skin lesions in calves and goats. Calves skin lesions were cured within 27-30 posttreatment days and goats skin lesions were cured within 24-27 post-treatment days.

Table 1. Comparative efficacy of Ivermectin, Dadmardan and Dadmardan \& Neem leaves against skin lesions in calves

\begin{tabular}{|c|c|c|c|c|c|c|c|c|}
\hline $\begin{array}{l}\text { Experi- } \\
\text { mental } \\
\text { days }\end{array}$ & $\begin{array}{c}\text { Area }\left(\mathrm{cm}^{2}\right) \\
\text { of skin } \\
\text { lesion in } \\
\text { Group A } \\
\text { (control) } \\
\text { (mean } \pm \text { SE) }\end{array}$ & $\begin{array}{c}\text { \% of } \\
\text { wound/ } \\
\text { lesion } \\
\text { area } \\
\text { increased }\end{array}$ & $\begin{array}{l}\text { Area }\left(\mathrm{cm}^{2}\right) \\
\text { of skin } \\
\text { lesion in } \\
\text { Group B } \\
\text { after } \\
\text { application } \\
\text { of the } \\
\text { Ivermectin } \\
\text { (mean } \pm \mathrm{SE} \text { ) }\end{array}$ & $\begin{array}{c}\% \text { of } \\
\text { wound/ } \\
\text { lesion area } \\
\text { reduction }\end{array}$ & $\begin{array}{c}\text { Area }\left(\mathrm{cm}^{2}\right) \\
\text { of skin } \\
\text { lesion in } \\
\text { Group C } \\
\text { after } \\
\text { application } \\
\text { of } \\
\text { Dadmardan } \\
\text { ointment } \\
\text { (mean } \pm \text { SE) }\end{array}$ & $\begin{array}{c}\text { \% of } \\
\text { wound/ } \\
\text { lesion area } \\
\text { reduction }\end{array}$ & $\begin{array}{c}\text { Area }\left(\mathrm{cm}^{2}\right) \\
\text { of skin lesion } \\
\text { in Group D } \\
\text { after } \\
\text { application } \\
\text { of combined } \\
\text { ointment } \\
\text { (Dadmardan } \\
\text { and Neeem) } \\
\text { (mean } \pm \text { SE) }\end{array}$ & $\begin{array}{c}\% \text { of } \\
\text { wound on } \\
\text { area } \\
\text { reduction }\end{array}$ \\
\hline 0 & $21.85 \pm 0.64$ & - & $93.33 \pm 0.33$ & - & $35.20 \pm 0.47$ & - & $75.17 \pm 0.61$ & - \\
\hline $3^{\text {rd }}$ & $21.95 \pm 0.85$ & 0.46 & $71.33 \pm 0.21$ & 23.57 & $23.67 \pm 0.40$ & 12.86 & $66.67 \pm 0.56$ & 11.30 \\
\hline $6^{\text {th }}$ & $22.15 \pm 0.56$ & 1.37 & $53.33 \pm 0.17$ & 42.85 & $26.00 \pm 0.42$ & 26.13 & $55.00 \pm 0.58$ & 26.83 \\
\hline $9^{\text {th }}$ & $\begin{array}{l}22.36 \pm 0 . .7 \\
7\end{array}$ & 2.33 & $37.67 \pm 0.24$ & 59.63 & $20.16 \pm 0.37$ & 42.72 & $45.30 \pm 0.59$ & 39.73 \\
\hline $12^{\text {th }}$ & $22.40 \pm 0.64$ & 2.51 & $16.66 \pm 0.16$ & 82.14 & $15.16 \pm 0.29$ & 56.93 & $34.00 \pm 0.56$ & 54.76 \\
\hline $15^{\text {th }}$ & $22.45 \pm 0.56$ & 2.74 & $6.70 \pm 0.10$ & 92.82 & $8.50 \pm 0.35$ & 75.85 & $20.00 \pm 0.46$ & 73.39 \\
\hline $18^{\text {th }}$ & $22.48 \pm 0.48$ & 2.88 & $1.53 \pm 0.07$ & 98.36 & $4.75 \pm 0.25$ & 86.50 & $9.40 \pm 0.40$ & 87.49 \\
\hline $21^{\text {st }}$ & $22.55 \pm 0.45$ & 3.20 & - & - & $2.53 \pm 0.20$ & 92.81 & $2.50 \pm 0.50$ & 96.67 \\
\hline $24^{\text {th }}$ & $22.60 \pm 0.36$ & 3.43 & - & - & $0.85 \pm 0.20$ & 97.58 & $0.60 \pm 0.32$ & 99.20 \\
\hline $27^{\text {th }}$ & $22.65 \pm 0.18$ & 3.66 & - & - & $0.25 \pm 0.12$ & 99.28 & $0.04 \pm 0.04$ & 99.94 \\
\hline $30^{\text {th }}$ & $22.70 \pm 0.09$ & 3.89 & - & - & $0.07 \pm 0.05$ & 99.80 & 0 & - \\
\hline
\end{tabular}




\section{M. Rahman and others}

The calves and goats treated with the dadmardan ointment (Group C), cured completely at 30 day of and 27 day of treatment in calves and goats respectively. On the other hand, calves and goats treated with the combined (dadmardan and neem leaves) ointment (Group D), cured completely at $27^{\text {th }}$ day and $24^{\text {th }}$ day of treatment in calves and goats respectively. Our present observations were agreed well with Ghani (2003), Habluetzel et al.(2007) and Ajose (2007) as they observed that the dadmardan and neen leaves act effectively against skin lesions ,tick and mite infestations.

The efficacy of ivermectin against skin lesions in calves and goats ointments was the highest considering the time required for healing as ivermectin treated animals skin lesions were cured within 18days whereas animals treated with the ointments of indigenous medicinal plants took 24-30 days (Table 1,2).Our present observations were agreed well with Hossain et al. (2002), Mannan et al. (1997) and Hossen and Mostofa (1999).Between two types of herbal ointments ,combined ointments (dadmardan and neem leaves) was more effective than the ointment of dadmardan leaves as animals treated with the combined ointment took 24-27 days whereas animals treated with the dadmardan ointment took 27-30 days.On the other hand, the indigenous medicinal plants (ointment form) against skin lesions in calves and goats showed slightly more effective than ivermectin. These findings have a correlation with the findings of Mostofa et al.( 1993). They applied neguvon ${ }^{\circledR}$ ointment with neem leaves against humpsore in cattle. They observed that $100 \%$ animals were cured in 30 days with the formulation (neguvon ${ }^{\circledR}+$ neem leaves). The finding of the present research work is highly correlated with the findings of Murdiati and Manurung (1991). They used an aqueous suspension of 50\% ketepung (C. alata) leaf in the treatment of $P$. cuniculi infestation in 10 New Zealand rabbits.

Table 2: Comparative efficacy of Ivermectin, Dadmardan and Dadmardan \& Neem leaves against skin lesions in Goats

\begin{tabular}{|c|c|c|c|c|c|c|c|c|}
\hline $\begin{array}{l}\text { Exper } \\
\text { i- } \\
\text { menta } \\
\text { l days }\end{array}$ & $\begin{array}{l}\text { Area }\left(\mathrm{cm}^{2}\right) \text { of } \\
\text { skin lesion in } \\
\text { Group A } \\
(\text { control) } \\
(\text { mean } \pm \text { SE) }\end{array}$ & $\begin{array}{c}\% \text { of } \\
\text { wound/ } \\
\text { lesion area } \\
\text { increased }\end{array}$ & $\begin{array}{l}\text { Area }\left(\mathrm{cm}^{2}\right) \\
\text { of skin } \\
\text { lesion in } \\
\text { Group B } \\
\text { after } \\
\text { application } \\
\text { of the } \\
\text { Ivermectin } \\
\text { (mean } \pm \mathrm{SE} \text { ) }\end{array}$ & $\begin{array}{c}\text { \% of } \\
\text { wound/ } \\
\text { lesion area } \\
\text { reduction }\end{array}$ & $\begin{array}{c}\text { Area }\left(\mathrm{cm}^{2}\right) \\
\text { of skin } \\
\text { lesion in } \\
\text { Group C } \\
\text { after } \\
\text { application } \\
\text { of } \\
\text { Dadmardan } \\
\text { ointment } \\
\text { (mean } \pm \mathrm{SE} \text { ) }\end{array}$ & $\begin{array}{c}\text { \% of } \\
\text { wound/ } \\
\text { lesion area } \\
\text { reduction }\end{array}$ & $\begin{array}{l}\text { Area }\left(\mathrm{cm}^{2}\right) \text { of } \\
\text { skin lesion in } \\
\text { GroupD after } \\
\text { application of } \\
\text { combined } \\
\text { ointment } \\
\text { (Dadmardan } \\
\& N e e m) \\
(\text { mean } \pm \text { SE) }\end{array}$ & $\begin{array}{l}\text { \% of } \\
\text { wound } \\
\text { /lesion on } \\
\text { area } \\
\text { reduction }\end{array}$ \\
\hline 0 & $2.35 \pm 0.18$ & - & $10.33 \pm 0.26$ & - & $35.33 \pm 0.25$ & - & $12.37 \pm 0.11$ & - \\
\hline $3^{\text {rd }}$ & $2.37 \pm 0.22$ & 0.85 & 9.410 .21 & 8.90 & $32.10 \pm 0.20$ & 9.14 & $11.57 \pm 0.15$ & 6.47 \\
\hline $6^{\text {th }}$ & $2.40 \pm 0.15$ & 2.12 & $7.45 \pm 0.24$ & 27.87 & $28.23 \pm 0.23$ & 2.095 & $9.93 \pm 0.13$ & 19.72 \\
\hline $9^{\text {th }}$ & $2.45 \pm 0.14$ & 4.25 & $4.93 \pm 0.20$ & 52.27 & $23.20 \pm 0.19$ & 34.33 & $7.90 \pm 0.17$ & 36.13 \\
\hline $12^{\text {th }}$ & $2.46 \pm 0.17$ & 4.68 & $2.94 \pm 0.15$ & 71.53 & $18.50 \pm 0.18$ & 47.63 & $5.70 \pm 0.16$ & 53.92 \\
\hline $15^{\text {th }}$ & $2.50 \pm 0.20$ & 6.38 & $1.17 \pm 0.07$ & 88.67 & $12.50 \pm 0.13$ & 64.61 & $3.00 \pm 0.18$ & 75.74 \\
\hline $18^{\text {th }}$ & $2.51 \pm 0.15$ & 6.80 & $0.10 \pm 0.04$ & 99.03 & $5.30 \pm 0.20$ & 84.99 & $1.10 \pm 0.17$ & 91.10 \\
\hline $21^{\text {st }}$ & $2.53 \pm 0.10$ & 7.65 & - & - & $1.83 \pm 0.19$ & 94.82 & $0.32 \pm 0.10$ & 97.41 \\
\hline $24^{\text {th }}$ & $2.56 \pm 0.12$ & 8.93 & - & - & $0.55 \pm 0.05$ & 94.44 & $0.08 \pm 0.09$ & 99.35 \\
\hline $27^{\text {th }}$ & $2.60 \pm 0.08$ & 10.63 & - & - & $0.04 \pm 0.03$ & 99.88 & 0 & - \\
\hline
\end{tabular}

After 4 weeks of treatment, there was a significant reduction in the number of mites on the ears of the treated animals; the total area of the ears infested by P. cuniculi and covered by scabs was also reduced in treated animals. On the other hand, our present observations were somewhat different because in our experiment, the realing rate were $98.36 \%$ and $99.03 \%$ in ivermectin, $99.80 \%$ and $99.88 \%$ in dadmardan ointment and $99.94 \%$ and 99.35\% in combined ointments in calves and goats respectively but Hossain et al.(2002) and Islam et al.(2003) found $100 \%$ healing rate in animals those were treated with ivermectin. 
In case of control group (Group A),the lesions were aggravated gradually. Our present findings were same as Hossain et al.(2002).there was no adverse effects found in the calves and goats those were treated with ointments of the indigenous medicinal plants against skin lesions. Our present observation was agreed well Bagherwal (1999).

Considering the above findings, we want to conclude that in the treatment of skin lesions in calves and goats herbal preparation may be used especially in the form of ointment .Herbal preparation are inexpensive ,easily available ,so ointments of indigenous medicinal plants especially dadmardan and neem leaves may be used as alternative drugs for the treatment of skin diseases.

\section{REFERENCES}

1. Ajose FO (2007). Some Nigerian plants of dermatologic importance. International Journal of Dermatology 46 (Suppl 1): 48-55.

2. Annonymous (1985). Asian Livestock. Vol.X.No 5 p 49.

3. Bagherwal, R.K. (1999). Acaricidal efficacy of AV/EPP/14 against Hyalomma anatolicum anatolicum in vitro and on naturallay infected cattle. Indian Veterinary Journal. 76(3): 196-198.

4. Chungsamrnyart N.,Jiwajinada S and Janasawan W( 1991).Larvicidal effect of plant crude-extracts on the topical cattle tick.. Kasetsart Journal of Natural Science.25:80-90.

5. Cullen PT(1991).Farm Animal Health (a practical guide). $1^{\text {st }}$ edn., Pergamon press.USA.p.105

6. Debnath, N. C., B. K. Sil, S. A. Selim, M. A. M. Prodhan and M. M. R. Howlader. (1990). A retrospective study of calf mortality and morbidity on small holder traditional farms in Bangladeh. Prevelence of Veterinary Medicine 9: 1-7.

7. Dey AS and Noorunddin M (1993).Economic impact of leather defects in Bangladesh. Bangladesh journal of Training and Development 6: 27-38.

8. FAO (1980).Animal Health Year Book.Food and Agricultural Organization .Rome.pp.173-201.

9. FAO (1997).Production Year Book . .Food and Agricultural Organization .Rome.United Nations

10. Ghani, A. 2003. Medicinal plants of Bangladesh with chemical constituents and Uses. 2nd edn., Asiatic society of Bangladesh Dhaka, Bangladesh, pp. 100-355.

11. Gill, B. S., Singh, J., Balakrish, P. and Hossain, M. 1988. Treatment of humpsore (Stephanofilariasis) of cattle with Ivermectin. Indian Journal of Animal Science. 58: 552-560.

12. Habluetzel.A, Carnevali.F, Lucantoni.L,Grana.Lm, Attili.A.R, Archilei.F, Antonini.M, Valbonesi.A, Abbadessa.V, Esposito.F, Esch.S.A.vander (2007). Impact of the botanical insecticide Neem AzalReg on survival and reproduction of the biting louse Damalinia limbata on angora goats. Veterinary-Parasitology, 144 (3/4): 328-337.

13. Hossain, A. (1994). Comparative efficiacy of modern anthelmintic against intestinal nematodiasis in cattle with that of neem seed (Azadiracta indica). M. Sc. (Vet. Sc.) Thesis, Dept. of Pharmacology, BAU, Mymensingh.

14. Hossain, M. L., Mostofa, M. and Saiful, M. (2002). Comparative efficacy of some indigenous medicinal plant and a patent drug ivermectin against stephanofilariasis in Cattle. Bangladesh Journal . of Animal Science. 31 (1-2): 69-73.

15. Hossen, M.L.and Mostofa, M. (1999). Efficacy of Ivermectin,tobacco leaf extract and tobacco-copper sulfate formulation in ticks and lice infestation in cattle. The Bangladesh Veterinarian.16 (2): 60-62.

16. Islam, A.,Mostofa, M.,Awal, M.A., Islam, M.R.,Alam,J.,Rahman,M.M.,Rahman,M.and Anwar, A.K.M.(2003). Efficacy of Ivermectin against gastrointestinal nematodes and ectoparasites in calves.Indian Veterinary Journal.80: 1173-1176.

17. Mannan,M.A.,Rafiq K.,Mostafa,M.and Hasan Q. (1997). Comparative efficacy of Ivomec ${ }^{\circledR}$ pour on . Neguvon ${ }^{\circledR}$ ointment and Neem-tobacco herbal preparation against naturally occurring humpsore lesions in cattle. The Bangladesh Veterinary Journal. 31 (3-4): 119-122.

18. Mostofa, M. (1983). Efficacy of some indigenous medicinal plants against gastrointestinal nematodiasis in cattle and their comparative activity with that of nemafex. M. Sc. (Vet. Sc.) Thesis. Dept. of Pharmacology. BAU, Mymensingh.

19. Mostofa, M., Awal, M. A. and Myenuddin, M. (1993). Comparative efficacy of indigenous medicinal plant, Neem (Azadirachta indica) and imported drugs against humpsore and other skin lesions of cattle. Bangladesh Agricultural University Research Progress 7: 519-523.

20. Murdiati, T.B. and Manurung, J. 1991. Study of the efficacy of keptepeng leaf (cassia alata L.) against psoroptic mange (Psoroptes cuniculi). in rabbits. Balai penelitian veterinary Journal ,Bogor, Indonesia Penyakit-Hewan. 23(41): 50-52.

21. Nath, K., Rajagopal and Garg, A.K. (1983). Water washed neem seed kernel cake as a cattle feed. The Journal of Agricultural Science, 101 (2): 323-324.

22. O’Brien, D.J., Gary, J. and O’Reilly, P. (1993). Control of sheep scab by subcutaneous infection of Ivermectin, Irish Veterinary Journal. 46(3): 99-101.

23. Safique, M. I. 1979. Studies of anthelmintic effects of pineapple (Ananus sativus). Leaves on sheep. M.Sc. (Vet. Sc) Thesis. Submitted to Department of Medicine, BAU, Mymensingh. 


\section{M. Rahman and others}

24. Samad, M. A. (2003). A report on "Evaluation of management practices, therapy and colostral immunity in the control of calf morbidity and mortality in Bangladesh." Submitted to the BAU Research System, Bangladesh Agricultural University, Mymensingh. pp 79.

25. Taher, M. A. (2005). Comparative efficacy of three indigenous medicinal plants (Turmeric, Garlic and Aloe) with locally available patent drug Nebanol against artificially induced wound in guineapigs. M.S. Thesis, Department of Pharmacology, Bangladesh Agricultural University, Mymensingh. p. 58.

26. Venugopal, K., Rao, R. Gaffar, A. A. 1992. Therapy of stephanofilarial ear sore in buffaloes, comparative efficacy of ivermetin and Amitas. Indian Journal of Veterinary Medicine. 12: 57-58.

27. Woodruff,H.B.andBurg,R.W.1986.The antibiotics explosion.In Discoveries in Pharmacology(Vol.3) (Parnham,J. andBruinvels,J.,eds) P. 338. 